\title{
A Discoursive Review of Galtung and Ruge's News Factors in Iranian Newspapers
}

\author{
Reza Kheirabadi \\ Department of Linguistics, Tarbiat Modares University, Tehran, Iran \\ Email: rkheirabadi@gmail.com \\ Ferdows Aghagolzadeh \\ Department of linguistics, Tarbiat Modares University, Tehran, Iran \\ Email: aghagolz@modares.ac.ir
}

\begin{abstract}
The criteria on which journalists and news editors judge about newsworthiness of an event or news story are called "news values". The most prominent and widely studied list of news values (also called news criteria or news factors) was proposed by Galtung and Ruge in 1965 in which twelve selection criteria such as frequency, threshold, unambiguity and meaningfulness were pinned down as the factors by which gatekeepers make decision about newsworthiness of a news item. This leading and seminal article rose many positive and negative reactions and for decades Galtung and Ruge's list of news values has been reviewed, revisited and criticized by many linguists and media experts. In this article we review the application of this set of news values in Iranian media atmosphere to observe which news values play the major role in selection process of newspapers in this middle east country. The data of this research are composed of 100 news stories gathered from four international morning newspapers published in Iran in winter 2010 and we try to distinguish the news values of Iranian newspapers based on Galtung and Ruge's (1965) list of news factors. The results of this study show that while reference to elite people (especially politicians) is the most important and frequent news value, some criteria which are not mentioned in Galtung and Rge's list of news values have a considerable role in news selection process of newspapers in Iran. The most considerable factor for which there is no room in Galtung's list is the impact of ideology and its role in overall news selection process. This study also shows that although the twelve factors of Galtung and Rug's list are influential in Iran media, we should not limit selection process to them and the role of social metalingual elements such as ideology and competition with other media in the gatekeeping process should not be ignored.
\end{abstract}

Index Terms—news values, discourse analysis, Galtung and Rouge, media

\section{INTRODUCTION}

Linguists, especially (Critical) Discourse Analysts, have shown a powerful interest to news analysis from various perspectives and within different approaches. For them, news as a type of discourse has been considered as a very interesting topic of linguistic analysis. Some remarkable and pioneering works such as van Dijk (1988), Fairclough (1989), Fowler (1991) and Bell (1991), are just some examples of linguistic studies which have been done in field of news and media analysis both in theory and practice. One aspect of news production process which has been studied by linguists for a long period of time is the selection process during which the journalists or the gatekeepers consider which news are worthy enough to be reported. Every day many different events happen all around the world but a very few number of them , after passing through a so called "gate keeping "process are published and broadcasted as news. The selectivity criteria of this judgment are technically known as news values (also called news factors or news criteria) and the history of this theoretical concept mainly goes back to 1965 and publication of Galtung and Ruge's seminal paper on news values in which they pinned down a list of twelve factors as news criteria according which the gatekeepers make decision about newsworthiness of events and news stories to be reported or not. Their research was originally the study of foreign news coverage in Norwegian newspapers and Galtung and Ruge intended to explain the selectivity criteria of three major international crisis in four Norwegian newspapers. However; the theoretical framework and set of twelve news values that they suggested in their article have been applied to many different types of news and became (arguably) the most frequently cited news values list proposed so far. Watson $(1998$, p.117) believes that: "The names of two Norwegian scholars, Johan Galtung and Mari Ruge, have become as associated with news value analysis as Hoover with the vacuum cleaner. Their model of selective gatekeeping of 1965, while not carrying quite the romance of the apple that fell on Newton's head, is nevertheless a landmark in the scholarship of media."

As Fowler (1991, p.13) mentions: “... a widely accepted analysis of news values in the following list of criteria factors formulated by Galtung and Ruge; are worth studying in detail and in particular. it is worth reflecting on the great extent to which the factors are cultural rather than natural". The values they identified are: (Note: F stands for Factor) (F1) frequency, (F2) threshold, (F3) unambiguity, (F4) Meaningfulness, (F5) Consonance, (F6) unexpectedness, (F7) 
continuity, (F8) composition, (F9) reference to elite nations, (F10) reference to elite people, (F11) reference to persons, (F12) reference to something negative (ibid, p.13)

Galtung and Ruge defines and describes each of these news factors as bellow:

1- Frequency: An event that unfolds within a publication cycle of the news medium is more likely to be selected than a one that takes place over a long period of time.

2- Threshold: Events have to pass a threshold before being recorded at all; the greater the intensity (the more gruesome the murder or the more casualties in an accident), the greater the impact and the more likely it is to be selected.

3- Unambiguity: The more clearly an event can be understood and interpreted without multiple meanings, the more likely it is to be selected.

4- Meaningfulness: The culturally familiar is more likely to be selected.

5- Consonance: The news selector may be able to predict (due to experience) events that will be newsworthy, thus forming a "pre-image" of an event, which in turn increases its chances of becoming news.

6- Unexpectedness: Among events meaningful and/or consonant, the unexpected or rare event is more likely to be selected.

7- Continuity: An event already in the news has a good chance of remaining in the news (even if its impact has been reduced) because it has become familiar and easier to interpret.

8- Composition: An event may be included as news less because of its intrinsic news value than because it fits into the overall composition or balance of a newspaper or news broadcast.

9- Reference to elite nations: The actions of elite nations are seen as more consequential than the actions of other nations.

10-Reference to elite people: Again, the actions of elite people, likely to be famous, may be seen by news selectors as having more consequence than others, and news audiences may identify with them.

11- Reference to persons: News that can be presented in terms of individual people rather than abstractions is likely to be selected.

12- Reference to something negative: Bad events are generally unambiguous and newsworthy. (Galtung and Rouge 1965 cited in O'Neill and Harcup , 2009,pp.164-165)

Although the above mentioned list of news values has been criticized by many scholars including both media experts and linguists, it is considered as the most classic and widely studied news values classification and as Brighton and Foy (2007, p.7) write: "Galtung and Ruge's work remains an ideal starting-point for any serious discussion of news values". Palmer, (1998, p. 378) also believes that Galtung and Ruge were arguably the first to provide a systematic list of news values. McQuail (1994, p. 270 cited in O'Neill and Harcup , 2009, p.164 ) describes this list as "the most influential explanation of news values". However, these amount of admiration could not stop criticisms and further explorations and amendments in the area of news selection. O'Nile and Harcup (2009) briefly but very exactly describe the development of theoretical and practical achievements in this field of research from 1965 since start of the new millennium to depict the attempts done by media scholars during the recent half of century and show where we are standing at the moment. Many lists of news values/criteria have also been suggested by media researchers and journalists, for example, Denis MacShane (1979, p.46) subdivided newsworthy events into the following categories: Conflict, Hardship and danger to the community, Unusualness, Scandal and Individualism.

Harcup and O'Neill's (2001 cited in Brighton and Foy,2007) study of the printed press resulted in their attempt to revise and update Galtung and Ruge's list as the following: Power élite, Celebrity, Entertainment, Surprise, Bad news, Good news, Magnitude, Relevance, Follow-ups and Media agenda. Hall (in Cohen and Young, 1981) distinguishes between two types of news values which is basically a distinction between normal and ideological news values:" Hall specifically distinguishes between what he terms 'formal' news values (broadly the approach analysed in the last section, starting with Galtung and Ruge) and 'ideological' news values. His 'formal' news values are:

Linkage: Is the story linked, or capable of being linked, with a prior event, happening,

occurrence?

Recency: Has it happened recently?

Newsworthiness of event/person: This criterion may be thought to pose or beg more

questions than it answers!

Crucially, Hall goes on to distinguish between the sort of formal news values outlined by Galtung and Ruge (and Ostgaard), and what he terms ideological news values. He contrasts the foreground structure of news and the events

reported with the hidden 'deep structure'. This involves what he describes as the 'consensus knowledge' of the world, which, he argues, provides a framework within which the news operates" (Brighton and Foy,2007, pp.9-10)

Although it is worth beginning the discussion with a brief review of Galtung and Rug's news values lists and its pros and cons, the aim of this paper is not to prepare a list of news values proposed by other scholars and to have a more clear picture of such attempts interested readers can refer to works mentioned above and some other recent researches such as Albert Braun (2009) in which more complete lists of news values are mentioned and classified. In this article, we study newspapers of Iran to find the most frequent Galtung and Ruge's news values regarded by Iranian journalists in news selection process. Our aim, in addition to recognizing the selectivity criteria in Iranian media especially 
newspapers is to see if Galtung and Ruge's suggested list of news values is empirically competent enough to explain the selection process in Iranian newspapers or there are some missing criteria which should be added to the list.

\section{Data And Methodology}

The data of this research was gathered from four Iranian morning newspapers of Iran News, Tehran Times, Iran Daily and Keyhan International (all of them known as international newspapers because they are published in English language and not domestic language of Iran which is Persian).we gathered the main story published on the front page of these newspapers for one month (in September 2011) and 100 news stories were selected altogether. The newspapers we used as the source of the data are the most widely spread daily newspapers of Iran published in English and they are belonging to both major political campus of thought in Iran (conservatives and reformists).

Each news story might be consisted of one or more than one news values. In recognizing the main news values of each story, in addition to the definitions, hints, and methods suggested by Galtung and Ruge in their research, we also used the following checklist:

-What is/are the main news value(s) of the title of each news story? The title of the news is a mirror reflecting its gist, as a result, titles play pivotal role in linguistic analysis of news stories since the earliest researches done by linguists especially CDA analysts.

-What is the type of the news? Is it a domestic or foreign one? If it is foreign news story, which element makes it interesting for Iranian audiences?

-Who is/are the main actor(s) of the news? Can they be considered as elite people (politicians, experts, famous art and sport faces) and organizations?

- Is the news centered on an interview? Who is the reference person or organization in the interview?

-Does the story have any follow-ups? Is it referring to a previous event or news story?

- Is there any reference to numbers and scales in the news? Are the numbers considered as magnificent or not?

-Is the theme of the news positive or negative? Is it telling a sad/ threatening story or a happy one?

Although in most cases there were clear demarcation among news values, in some cases we used our intuition and background knowledge in finding the relevant news values. In those news in which we could find more than one news factors, the categorization of news values is order irrelevant. Finally, we recognized 215 news values in the data corpus, some of them had collocation with other news values. The derived news values were sorted out and categorized within Galtung and Rouge's theoretical framework and in the following section we analyze the data.

\section{DATA ANALYSIS}

In this section, we analyze the recognized news values and the proportion of each of the twelve news factors. Table number one shows the total number of news values and the percentage of each news values in the corpus:

TABLE NO. 1

\begin{tabular}{|l|l|l|l|}
\hline No & News Values & Number of news values in the corpus & Percent \\
\hline 1 & F10 & 76 & $\% 35 / 3$ \\
\hline 2 & F5 & 55 & $\% 25 / 5$ \\
\hline 3 & F4 & 23 & $\% 10 / 6$ \\
\hline 4 & F6 & 17 & $\% 7 / 9$ \\
\hline 5 & F12 & 12 & $\% 5 / 58$ \\
\hline 6 & F1 & 10 & $\% 4 / 58$ \\
\hline 7 & F9 & 9 & $\% 4 / 1$ \\
\hline 8 & F2 & 8 & $\% 3 / 72$ \\
\hline 9 & F7 & 4 & $\% 1 / 86$ \\
\hline 10 & F11 & 1 & $\% 0 / 46$ \\
\hline 11 & F8 & 0 & $\% 0$ \\
\hline 12 & F3 & 0 & $\% 0$ \\
\hline Total & F1-F12 & 215 & $\% 100$ \\
\hline
\end{tabular}

As it is obvious in the table above, reference to elite people (F10) is the most frequent news values considered in the body of data studied in this research. In other words, elite people are most important source of newsworthiness for Iranian newspapers and speeches and actions of this group of society are highly interesting for the media. Although the term 'elite people' is considered ambiguous by some scholars, we can observe that newspapers are eager to cover things done and said by let us call it the powerful (with its meaning shade from CDA studies) group of the society. In Galtung and Ruge's paper the exact meaning of elite people are not demarcated in details and there is no difference between a rock star and a Nobel prize winner in this sense but our study showed that Iranian newspapers are mostly interested in covering the news related to politicians (the president, member of parliament, ministers and members of the cabinet are of the most importance for Iranian newspapers). This result is in accordance with some other lists of news values which reiterate the importance of elite people especially politicians in news selectivity. The following is only a brief sample of the long list of news values related to the concept of elite people especially the politicians: 
Celebrity (Ruehlmann,1979), Elitism(Gregory \& Miller, 1998), Famous faces (Ryan, 1991), Presidential candidates (Gans, 1979); Power elite (Harcup \& O'Neill, 2001), Celebrity (Harcup \& O'Neill, 2001), Government conflicts and Disagreements (Gans,1979), Governmental Politics (O’Sullivan et al., 1983); Political importance (Herbert,2000)

In general, as Golding and Elliott(1979) mentions “...Clearly big names attract audiences, but there is a circularity in that big names become famous by virtue of their exposure." It is also worth to mention that in Iran most of the newspapers are supported by government financial aids and it may be considered as a reason of media interest to cover the news related to the political faces.

As it is shown on the table number one, the second most frequent news values is consonance (F5) which means if the event matches the media's expectations or not. This notion is also known as 'angle' or view point of the media. It is said that if the media expect something to happen, it will. It seems that Critical Discourse Analysis (CDA) approach to news analysis is very fruitful in this field of study and the works of linguists such as van Dijk (1988), Fowler (1991), and Fairclough (2002) reveals the role of ideology and view point in news production process. However, the works mentioned on the above line are not the only linguistic attempts to explain the role of metalingual (social, historical, cognitive, economic and political) factors on news production. Chomsky and Herman (1988) in their propaganda model suggest that "selection of topics is one of the key ways in which the media fulfill their "societal purpose" of inculcating "the economic, social, and political agenda of privileged groups that dominate the domestic society and the state." (O’Neil and Harcup,2009, p.169).

It is worth to mention that Consonance is not limited only to geographical nearness but to cultural proximity also. For example, Iranian newspapers show a clear interest to events happening in Syria, a geographically not very near country but culturally a very proximate neighbor. Consonance is a news factor which is mentioned in various news values lists under different names such as Cultural Resonance (Ryan,1991), Pre- Fabrication (Bell, 1991), Predictability and Routine ( McQuail,2000).

The two factors of $\mathrm{F}(10)$ and $\mathrm{F}(5)$ are the most prominent news factors in Iranian newspapers in a way that these two factors can be regarded as news values of half of the news studied in this research. These two factors have been in collocation with each other in 42 percent of news stories we studied in this research which means that in those news which have more than one news values, the combination of $\mathrm{F}(10)$ and $\mathrm{F}(5)$ in the corpus we studied is the most frequent one. It seems that the most typical news in Iranian newspapers is those in which an elite person (mostly a person with high socio-political rank is speaking or commenting about a consonant matter which is considered as relevant and interesting both for media and audiences.

In the following, we review the role of other news values in the body of data we studied in the current research.

$\mathrm{F}(1)$ : We could not find any news item which was selected only due to its frequency. It seems that frequency is a complementary news values which is playing role besides other news values. The reason of this finding is maybe related to the modern developments in media especially the availability of internet in Iran. While almost everybody has access to news websites the recency of news is an element taken for granted. It is a necessity for news to be new and recent but it is a necessary condition not a sufficient one! Iranian newspapers have their techniques to cover the long span stories; one of them is using the newspaper's online edition to cover very urgent and recent events. It seems that emergence of online editions has had a considerable effect on prominence of $F(1)$.

$\mathrm{F}(2)$ : We did not find any significant news story in which the event has a considerable threshold. However, in some cases we observed the application of indefinite pronouns and quantifies such as "many, most, some and so on so forth.

F(3): Opposite its name, Unambiguity is one of the most ambiguous news values suggested by Galtung and Ruge.

It is not a value of an event but mostly the style and characteristic of composing level. It is worth to mention that in some news ambiguity in the event is considered a value but in general the composition of the news should be as unambiguous as possible. We found $\mathrm{F}(3)$ a general prerequisite of writing level of news as a result its role as a mere news value seems to be under question.

F(4) Meaningfulness to audiences of the newspaper is a highly frequent news values in our data corpus, the role of this news value is most prominent in foreign news about those countries far from Iran geographically but near to it culturally.

$\mathrm{F}(6)$ : Unexpectedness is another classic news value which is mentioned in many other news lists under different names (such as The Unusual (Herbert, 2000), Surprise (Hetherington, 1985; Harcup \& O’Neill, 2001) and Oddity (Ruehlmann, 1979)) but we find it a general characteristic of the event which is selected to be reported as news. The number of news in which the role of unexpectedness is actually central was not considered significant in our research.

F(7): Continuity which is also known as Follow-up (Harcup \& O'Neill, 2001) and CO-option (Bell, 1991) plays a rather insignificant role in our study. However we found that if we broaden the term to competition with other newspapers and media then the impact of this news value will be more considerable. It seems that in Iranian media atmosphere competition with other media is more influential than continuity.

F (8): We found it really difficult to judge about the intention of journalists and editors to balance the composition of the page by their final product which in our study is front page of the edition of the newspapers. However, it seems at least on front pages this factor is not the major final value for news selection in most cases.

F (9): Reference to elite nations (in our study European and neighboring countries) is a relatively important factor in news selection process of Iranian newspapers. EU members and the USA besides geographically or culturally close 
countries to Iran were the most significant countries in our research. It is necessary to mention that reference to international organizations and associations (such as the UN and the International Atomic Energy Agency (IAEA)) is also a crucial news values at least in foreign news of Iranian newspapers.

F(11) Reference to person which is called as Personalization (Gregory and Miller,1998) or News about people (Ross Commission in Hetherington, 1985) says that tangible news in which people are main actors are of higher value in comparison with abstract news. Although we found human actors and participants in most of data, almost in all cases the theme of the news was something (at least to somehow) abstract (mainly the US threats and political clash between Iran and western countries). As a result, we did not find this factor a significantly important one in Iran media.

F (12) Only in less than 6 percent of news studied in this research we found a negative theme which is seemingly not very considerable amount. However, as mentioned above, many news were about political quarrel between Iran and West but these types of news cannot necessarily be interpreted as Referring to something to negative. We found majority of these news related to Consonance factor instead.

\section{CONCLUSION}

In this paper, we studied Iranian newspapers within Galtung and Ruge's news values framework and found that reference to elite people (mostly top ranked politicians) and consonance are the most frequent news factors in Iran journalistic atmosphere. However, we should keep in mind that this research was done on data selected from English language (known as International) newspapers and maybe the results cannot be extended to Persian language domestic newspapers. We also found that while some classic news values such as continuity and threshold are not significantly crucial in Iranian newspapers, the role of some metalingual factors which have central position in CDA approach (such as ideology, competition and relations of power) is undeniable in news selectivity in Iran society. It seems that CDA and ethnographic studies (see Journal of Pragmatics special issue Vol 43, issue 7 May 2011 for information on discoursive and ethnographic perspectives on news production) can explain some hidden and missing aspects of news selection and production more profoundly. However it does not mean that Galtung and Ruge's list of news values is seriously under question. Further complimentary researches are needed to be done and ethnographic linguists should go to newsrooms to discover the in action criteria of news production process. This paradigm shift from product to process oriented approach is a strong trend in media studies which should be regarded by new generation of linguists. The final point is that in Galtung and Ruge's news values list the lack of level separation is obvious and in future studies researches can focus on technical and exclusive news factors in pre- production (choosing interesting event), production (news composition) and post production(publication or broadcasting) levels which may lead to more theoretical and applied coherence and exactness.

\section{REFERENCES}

[1] Aghagolzade, F. \& R. Kheirabadi. (2008). A linguistic study of news values in Iranian press. The international journal of humanities of the Islamic republic of Iran 15(1),1-7.

[2] Albert Braun, J. (2009). Rehashing the Gate: News Values, Non-News Spaces, and the Future of Gatekeeping. M.S Thesis, Cornell University.

[3] Allern, S. (2002). Journalistic and commercial news values: News organizations as patrons of an institution and market actors. Nordcom Review, 23(1-2), 137-152.]

[4] Bell, A. (1991). The language of news media. Oxford: Blackwell.

[5] Brighton, P. and D. Foy, (2007). News values. London: Sage Publications.

[6] Chomsky, N. \& E. S. (1998). Manufacturing consent. New York: Pantheon Books.

[7] Cohen, S. \& J. Young (eds.) (1981). The Manufacture of News: Deviance, Social Problems and the Mass Media (2nd edn.). London: Constable. pp. 69-90.

[8] Cook,G. (1992). The discourse of advertising. London: Routledge.

[9] Fairclough, N. (2003). Analysing discourse. London: Routledge.

[10] Fairclough, N. (1989, 2001). Language and Power. Longman.

[11] Fairclough, N. (1992). Discourse and social change. Cambridge.

[12] Fairclough, N. (1995). Media discourse. London: Arnold.

[13] Fowler, R. (1991). Language in the news. London: Routledge.

[14] Galtung, J. \& M. H. Ruge. (1965). The structure of foreign news: The presentation of the Congo, Cuba and Cyprus crises in four Norwegian newspapers. Journal of Peace Research, 2 (1), 64-90.

[15] Gans, H. J. (1979). Deciding what's news: A study of CBS Evening News, NBC Nightly News, Newsweek and Time. New York: Pantheon Books.

[16] Golding, P. \& P. Elliott, (1979). Making the news. In H. Tumber (ed.), News: A reader, New York: Oxford University Press, 112-120.

[17] Gregory, J. \& S. Miller, (1998). Making news out of science. In Science in public Communication, culture, and credibility, New York: Plenum, 108-114.

[18] Grice, H. P. (1975). Logic and conversation. In Cole, P. \& J. L. Morgan (eds.) Syntax and semantics: Speech acts 3. New York: Academic Press. 58-85.

[19] Grice, H. P. (1989). Studies in the way of words. Cambridge: Harvard University Press. 
[20] Hall, S. (1973). The determinations of news photographs. In S. Cohen \& J. Young (Eds.), The manufacture of news: Social problems, deviance and the mass media, Communication and society. Beverly Hills: Sage Publications, 176-190.

[21] Hall, S., Chritcher, C., Jefferson, T., Clarke, J. and Robects, B. (1981). The social production of news, in S. Cohen and J. Young (eds) The Manufacture of News: Deviance, Social Problems and the Mass Media (2nd edn). London: Constable. pp. 3363.

[22] Harcup, T. \& D.O'Neill. (2001). What is news? Galtung and Ruge revisited. Journalism Studies, 2(2), 261-280.

[23] Harrison, J. (2006) News. Abingdon: Routledge.

[24] Herbert, J. (2000). The purpose and meaning of news. In Journalism in the digital age: Theory and practice for broadcast, print and on-line media, Boston: Focal Press, 59-73.

[25] Hetherington, A. (1985). What's news? Who makes the news? In News, newspapers and television , London: Macmillan Press, $1-21$.

[26] Hoey, M. (2001). Textual interaction. London: Routledge.

[27] Lindblom, K. (2006). Cooperative Principle in J. L. Mey (ed.) (2009) Concise Encyclopedia of Pragmatics Oxford: Elsevier Ltd, 151-158.

[28] McQuail, D. (2000). McQuail's mass communication theory (4th ed.). Thousand Oaks: Sage Publications.

[29] McQuail, D. (1994). Mass communication theory. London: Sage.

[30] MacShane, D. (1979). Using the Media. London: Pluto Press.

[31] O’Neill, D. and T. Harcup. (2009). News values and selectivity. In T. Wahl-Jorgensen, K. Hanitzsch, (2009). The handbook of journalism studies, New York: Routledge.

[32] O'Sullivan, T., J. Hartle, D. Saunders, \& J. Fiske, (1983). News values. In Key concepts in communication, Studies in communication. New York: Methuen, 153-155.

[33] Palmer, J. (1998). News production, news values. In A. Briggs \& P. Cobley (Eds.), The media: An introduction Harlow: Longman, 117-132.

[34] Ruehlmann, W. (1979). Ideas. In Stalking the feature story. New York: Vintage Books, 94-114.

[35] Ryan, C. (1991). What's newsworthy? In Prime time activism: Media strategies for grassroots organizing. Boston: South End Press,31-52.

[36] Sande, O. (1971). The perception of foreign news. Journal of Peace Research, 8(3/4), 221-237.

[37] Tunstall, J. (Ed.). (1970). Media sociology. London: Constable.

[38] Van Dijk, T. (1988). News as Discourse. Hillsdale, NJ: Erlbaum.

[39] Warner, M. (1970). Decision-making in network television news. In Media sociology: A reader, Chicago: University of Illinois Press, 158-167.

[40] Watson, J. (1998). The news: Gates, agendas and values. In Media communication: An introduction to theory and process (pp. 105-129). London: Macmillan Press.

[41] Yule, G. (2000). Pragmatics. London: Oxford University Press.

[42] Zelizer, B. (2004). Taking journalism seriously: News and the academy. London: Sage.

Reza Kheirabadi was born in Tehran, Islamic Republic of Iran in 1979. He is a PhD candidate of General Linguistics in Tarbiat Modares University (Tehran, Iran) and received his M.A. from the same university in 2006.He is now passing a 6 months scholarship in Gent, Belgium with News Text and Talk (NT\&T) Research Group.

$\mathrm{He}$ is currently working for Organization for Educational Research and Planning (OERP) which is the official body to prepare textbook materials and curriculum planning in Islamic Republic of Iran. He also has the experience of working for leading Iranian newspapers and news agencies as journalists and translator. His main research interests are News production process, Language of News, Critical Discourse Analysis of news and ethnographic study of journalistic activities in Iran. His MA thesis was also about linguistic study of news values in press of Iran.

Mr. Kheirabadi is a research assistant of NT\&T and a member of Public Relations Expert Association of Islamic Republic of Iran.

Ferdows Aghagolzadeh is associate professor of General linguistics in Tarbiat Modares University, Tehran, Islamic Republic of Iran. He received his $\mathrm{PhD}$ in 2001 from Tarbiat Modares University. He has been the advisor of many master and $\mathrm{PhD}$ researches.

His main fields of interests are (Critical) Discourse Analysis, Sociology, Dialectology, Persian Language Teaching and related subjects. He has authored many articles and books, among books Critical Discourse Analysis (Tehran, Iran: Elmi Farhangi Publications, 2005) and Analysis of Radio Discourses Based on Linguistic Theories and Strategies (Tehran, Iran: Tarhe Now, 2009) to the subject of this article. 